\title{
SOME NOTES ON HEBREW MATTERS, LITERARY AND OTHERWISE.
}

\author{
By Rev. T. Witten Davies, B.A., Ph.D., \\ PROFESSOR OF SEMITIC LANGUAGES, \\ UNIVERSITY COLLEGE OF NORTH WALES.
}

When in the summer semester of $1892 \mathrm{I}$ asked the late eminent Old Testament scholar, Dr. Dillmann, of the University of Berlin, to tell me of important recent Hebrew grammars, he put in the first place the great grammar of Eduard König, then Hebrew Professor at Rostock, now of Bonn. He said that no other modern book gives so complete and accurate a conspectus of what the old Hebrew grammarians thought and wrote about their own language.

Since 1892, the learned and laborious author (who, at the Oriental Congress in August last, showed himself as vigorous as ever) has added two volumes to the one published in 1887, though on the title pages these volumes are called Part I, 1st and 2nd half, and Part II, the latter volume, issued in 1897, dealing with the Syntax. I have found this great work of extraordinary value, especially when searching for information on out-of-the-way points. I think I should add that for examples of Hebrew forms I find no reference book to touch Böttcher's immense Grammar, which devotes nearly 1,400 8-vo. pages to the accidence alone-the part dealing with syntax never came out.

The ideal elementary Hebrew Grammar has yet to appear. Though I get my first year pupils to buy $\mathrm{H}$. $\mathrm{B}$. Davidson's Hebrew Introductory Grammar, it is on account of the exercises mainly, as I find it necessary to deliver my own lectures on the subject.

The Germans, with the new Grammars of Steuernagel, Hollenberg, Budde, and the new editions of Strack,

1 T. \& T. Clark, 1892, page 4. 21895, p. 305. 
and other recent works, are far ahead of the British in the matter of Hebrew Grammars for beginners.

König has now published a small Hebrew Grammar at the price of three shillings and sixpense (M. 3.50) containing the lectures delivered by the author, first at Leipzig, and subsequently at Bonn. In it he attempts to combine the scientific and the practical, avoiding matters that are abstract and doubtful. The chief merit of the book is that in a brief compass the principles enumerated and elaborately discussed in the larger work are here succinctly stated, with many additional hints suggested by the author's later studies and experience as teacher. Then there are well-graded exercises which teachers and students will find useful. All through when treating of the forms, Arabic (transliterated) is used, and at the end there is an admirable summary of the accidence of Arabic, all in European type, just as much as an ordinary student needs to know for purposes of comparison with Hebrew.

Though the book is small (111 pages, with 88 pages of appendix-exercises, vocabularies, etc.,) the whole subject is discussed, including the Syntax. The treatment is quite original and interesting and those who have made a study of the language will find here a good deal to inform and stimulate. One misses the paradigms of nouns, verbs, etc., which other grammars contain and which students find convenient for reference; though the contents of these paradigms are found scattered throughout the volume.

Some things occur in the Syntax which are lacking in even such works as the excellent "Hebrew Syntax" of A. B. Davidson, as, for example, the brief statement about the Reciprocal pronoun. Other things are omitted here which should find a place, such as, e. g., the use of the "Inner Hiphil," which is so important for the understanding of the Hebrew Bible. There are here and there references to the larger work, for which readers who 
possess the latter will be thankful. It is a pity, however, that there is no Index, though this lack is to some extent made up for by a good list of contents.

\section{A New Edition of Strack's \\ "Einleitung in den Talmud."}

The fourth edition of Strack's very useful "Introduction to the Talmud" has just made its appearance, greatly enlarged and improved, and therefore more helpful than ever to students who wish to understand the contents of what has been called the "Mare Talmudicum" and the way in which they are arranged. It has always appeared to me a mystery that so invaluable a vade mecum to the student of the Bible and the Talmud has not been issued in English, for its equal is not to be found in our own or in any other language. Dr. M. Miehziner, an American Jew, published in English a similar work in 1894 , but at three times its price, though it has not nearly its fulness or its accuracy. Any English publisher who issued an English edition of this admirable synopsis of what is knowable about the Talmud would confer an unspeakable boon on the English-speaking clergy and laity.

The useful work by Revs. W. O. E. Oesterley, D.D., and G. H. Box, M.A., entitled "The Religion and Worship of the Synagogue," touches on the subject, but necessarily in a brief way, and one has to guard against some inaccuracies in this interesting book. See review by the present writer in "Review of Theology and Philosophy," October, 1908; though I should like to qualify and modify some of my statements regarding the knowledge of Hebrew exhibited by the authors.

\section{Anent Some Technical Terms for Old Tespament Sacripioe.}

In the new and greatly improved edition of his "Hebräische Archaeologie"' (1907), Benzinger gives a classi- 
fication of animal sacrifices mentioned in the Old Testament which, as far as I am aware, has not been suggested before: see p. 366f., and especially note 2 on p. 366.

According to him the Hebrew word $z e b a k h$, which in the $\mathrm{P}$ code denotes animal as opposed to cereal (meal) offerings, is a generical term embracing under it two other terms as species, viz: olah (whole burnt offering, lit. what goes up ), and Shelamim, compensation offerings (wrongly translated peace offerings. The idea of peace is not in the root in any of its forms, nominal or verbal). The 'olah denotes an animal offering which is wholly consumed, i. e., wholly devoted to Yahwe; the Shelamim are such animal sacrifices as are shared by the offerers. The author refers to Hos. 3:4; 1 Sam. $2: 13 ; 6: 15$, as proof passages, but they hardly bear out what he maintains. Indeed, he is bound to admit that in actual usage zebakh is more commonly contrasted with 'Olah, perhaps in the sense above ascribed to Shelamim; see Num. 15: 3, 8; 2 Kings $10: 24$; Jer. $7: 21$; Amos $5: 22$, etc. In Leviticus ( $3: 1$, etc), zebakh is frequently prefixed to Shelamim, as if meaning animal sacrifice (generic) of the compensation kind (specific). In his excellent article on "Sacrifices and Offerings" in the new one-volume Hastings' Bible Dictionary, Professor A. R. S. Kennedy, D.D., of Edinburgh, makes no reference to the above view of Benzinger.

It is the usual thing to say that the distinction of zebakh (animal offering) and minkhah (cereal offering) is a peculiarity of the Priestly Code and of contemporary writings; but it is to be seen in our oldest prophetic writings and in a passage which is universally allowed to be genuine: see Amos $5: 22$.

On the other hand minkhah is used in its early general sense of "offering" throughout Malachi (see 1:13; $2: 12$ f.; and $3: 3 f$.) and I think also in Neh. 13:5, 9. This means of course no more than that these writings ante- 
date the introduction of the Priestly Code. Yet it can hardly be held that this Code, usually dated about B. C. 440 , did more than systematize and legalize customs which slowly came to be recognized.

\section{The Small Kethubim or Hagiography.}

Bishop Ryle and Professor F. Buhl on the canon contradict each other; which is right, if either?

In his "Canon and Text" (English Translation, Sec. 1), Franz Buhl (now Professor of Arabic at Copenhagen, formerly successor of Franz Delitzsch at Leipzig), says that the Kethubim Qetannim, or small writings (hagiographa) embrace Canticles, Ecclesiastes and Lamentations. Professor (now Bishop) Ryle, in his valuable work on the Canon of the Old Testament ${ }^{2}$ says, on the contrary, that the expression stands for "Canticles, Ecclesiastes and Esther." Both rest what they say on the Talmud (Bab) Berakok, 57 B. Now the Danish Professor and the English Bishop cannot both be right. Which, if either, are we to believe?

The only way to answer this question is to consult the Talmudic passage to which both refer, and this is what I have done. I give below as literal a rendering as I can. "These three are the small writings (hagiographa). He who sees the Song of Songs (Canticles) in a dream will hope for great piety. (He who sees) Qoheleth (Ecclesiastes) will hope for wisdom. (He who sees) Qenoth (Lamentations) is concerned about chastisement: and he who sees the roll (book) of Esther, for him a miracle will be performed."

It will be seen from the above that the Danish scholar is right and the British one wrong, if, as I think we must, we follow the letter of the passage, though the appended reference to Esther may give come support to the view that this book formed also a part of the Small Kethubim (hagiographa), which in that case will have four, not 
three, books, neither of the scholars named being right. But I think the context is against this interpretation. In the preceding paragraphs several triads or groups of three are mentioned; three Kings in Israel, three Prophets, three large Kethubim (Psalms, Proverbs and Job) and three small Kethubim, see above). About each unit of each triad some remark is made (see the extract above for examples). Now there are more than three of the things enumerated in the several triads, but three only are mentioned in each case. The reading of the three great hagiographs has certain effects, different in the different books (Psalms, etc.), and the same is true of the reading of the three small hagiographs-the word three being used in each case.

What is said of the roll Esther is added as applying to what is outside the triad and apparently the class. This is suggested by the fact that the words "He who reads" are repeated; in the second and third cases they are simply understood and in my translation above are bracketed. As a matter of fact there are eleven (not six or seven) books in the Kethubim. (Hagiographa) see Talmud (Bah) Baha Bathra 14 B. I do not know of any Talmudic passage or of any other Rabbinical passage in which the small hagiographs are discussed or even named; but there may be such for all that. 